\title{
GENETIC DIVERSITY AMONG SWEET POTATO CROPS CULTIVATED BY TRADITIONAL FARMERS ${ }^{1}$
}

\author{
PABLO FORLAN VARGAS ${ }^{2}$, ERIC WATZKE ENGELKING ${ }^{3}$, LUIS CARLOS FERREIRA DE ALMEIDA ${ }^{3}$, ELIEL \\ ALVES FERREIRA $^{4}$, HAMILTON CESAR DE OLIVERIA CHARLO 5
}

\begin{abstract}
The genetic variability within the crop species Ipomoea batatas is broad, hence, in order to support future breeding programs it is of the utmost importance that germplasm banks be created, conserved, and characterized. Therefore, the objective of this work was to rescue and evaluate the genetic divergence in sweet potato accessions collected in traditional communities of Vale do Ribeira Paulista. Sweet potato samples were collected from quilombos, indigenous villages, caiçaras communities, and small farms. The study was conducted between February 2013 and August 2014 in a randomized block design with three replications. Genetic material included 95 collected accessions and two commercial cultivars. Morphological characteristics of the accessions were evaluated and distances in the genetic distance matrix were estimated by means of multicategory variables, the data being subsequently clustered by the Tocher method. Analysis of the relative contribution of each characteristic and phenotypic correlation of descriptors was also performed. Results evidenced wide genetic diversity among the sweet potato accessions collected in Vale do Ribeira, which were not grouped according to the collection point. The descriptors that contributed more than $60 \%$ of genetic diversity included: leaf size, general leaf profile, immature leaf color, petiole pigmentation, predominant branch color, branch secondary color, stem length, cortical thickness, predominant periderm color, and periderm color intensity. Correlations between morphological descriptors was observed in $22.26 \%$ of the paired traits.
\end{abstract}

Keywords: Ipomoea batatas. Genetic variability. Germplasm. Plant breeding.

\section{DIVERSIDADE GENÉTICA ENTRE CULTIVARES CRIOULAS DE BATATA-DOCE CULTIVADAS POR AGRICULTORES TRADICIONAIS}

RESUMO - A variabilidade genética existente dentro da espécie Ipomoea batatas é amplo, assim, visando dar suporte a futuros programa de melhoramento genético da espécies é de suma importância que bancos de germoplasma sejam formados, conservados e caracterizados. Desta forma, objetivou com este trabalho resgatar e avaliar a divergência genética em acessos coletados em comunidades tradicionais do Vale do Ribeira Paulista. A condução do estudo foi realizada em campo da Fazenda da UNESP-Registro entre fevereiro/2013 a agosto/2014. O experimento foi conduzido em blocos casualizados, com 95 acessos coletados e duas cultivares comerciais, com três repetições. Foram avaliadas características morfológicas da parte aérea e da raiz dos acessos segundo a metodologia de Huamán. A estimativa da matriz da distância genética foi realizada por meio das variáveis multicategoricas, sendo posteriormente os dados agrupados pelo método de Tocher. Também realizou-se análise da contribuição relativa de cada característica e correlação fenotípica dos descritores. De acordo com os resultados, pode-se concluir que há ampla diversidade genética entre os acessos de batata-doce coletados no Vale do Ribeira; os acessos não agruparam em função do ponto de coleta; os descritores que contribuíram com mais de $60 \%$ da divergência genética foram o tamanho da folha, perfil geral da folha, cor da folha imatura, pigmentação do pecíolo, coloração predominante das ramas, cor secundária das ramas, comprimento da haste, espessura do córtex, cor predominante da periderme e intensidade da cor da periderme; A correlação entre os descritores morfológicos foi verificada em $22,26 \%$ dos pares.

Palavras-chave: Ipomoea batatas. Variabilidade Genética. Germoplasma. Melhoramento Vegetal. 


\section{INTRODUCTION}

Sweet potato (Ipomoea batatas (L.)) is listed among the seven main food crops in the world (NSA; OKON; ROBERT, 2013), and is one of the five major crops in 50 countries (THUMÉ et al., 2013), among other properties, because it produces large amounts of energy per unit area per unit time (MUKHOPADHYAY et al., 2011).

This vegetable contains many nutrients, including proteins, carbohydrates, minerals (calcium, iron, and potassium), carotenoids, dietary fibers and vitamins ( $\mathrm{C}$, folic acid and $\mathrm{B} 6$ ); it is low in fat and sodium. The characteristic yellow or purple color of the root pulp is due to the large amount of carotenoids or anthocyanins, in each case (PARK et al., 2014). In addition, it is recommended in the diet for patients with diabetes or pre-diabetes because of its low glycemic index.

Currently, China is the world's largest sweet potato producer, with a total of 788 million tons year ${ }^{1}$ and an average yield of $22.43 \mathrm{t} \mathrm{ha}^{-1}$, while Brazil is the $20^{\text {th }}$ producer, with an average productivity of $12.28 \mathrm{t} \mathrm{ha}^{-1}$, equivalent to $54.4 \%$ of the Chinese average yield (FAO, 2015). Cultivation in all states of the federation makes sweet potato the fourth most consumed vegetable in Brazil (OLIVEIRA et al., 2005). In 2012 sweet potato ranked sixth among the six main vegetables cultivated in the country, with a cultivated area of 40,100 hectares (IBGE, 2015).

Although it is an important crop for the country, particularly because of its social role as a highly nutritional and inexpensive food, and despite its potential to generate employment and income as it demands considerable manpower, sweet potato is still a poorly researched crop in Brazil, especially with regard to the development of new cultivars adapted to the different Brazilian regions. Currently used cultivars have become obsolete, low yielding, and quite susceptible to diseases, mainly foot-rot (Plenodomus destruens), and to nematode attack, especially by the genera Meloidogyne and Rotylenchulus.

The use of improved cultivars potentiates substantial increases in agricultural productivity. For over 70 years, breeding programs have been one of the pillars of high productivity in Brazilian agriculture. However, significant genetic gains in new varieties almost always implies the gradual loss of genetic variability, as the selection of superior genotypes is based only on those attributes correlated with high productivity. Therefore, it is important to characterize old genotypes cultivated by traditional producers, to maintain them in collections of germoplasm to avoid genetic erosion, and to use them in novel breeding programs aimed at creating superior genotypes for future use (MACIEL et al., 2016).

The variability within the genus Ipomoea is high due to the high ploidy level, typical of many cultivated species (RITSCHEL; HUAMÁN, 2002). However, much of this variability found in small farmer and low income peasants plots is being lost because of the changes in agricultural practices. Thus, it is of great importance to form and maintain gene banks with traditional varieties of sweet potatoes from different regions of the country. Based on a literature review, Silva et al. (2014) reported the existence of three gene banks of sweet potato in Brazil: 1) Embrapa Hortaliças, created in the 1980s and located in Brasília-DF; 2) Universidade Federal dos Vales do Jequitinhonha e Mucuri (UFVJM), located in Diamantina-MG; and 3) Universidade Federal do Tocantins (UFT), located in Palmas-TO, created in the $1990 \mathrm{~s}$.

Notwithstanding, this paradigm should be changed, as the society is looking for foods with high levels of bioactive compounds and better flavor that are sustainably produced and adapted to global climate change. To that effect, it is important to remember that there are still places with different settlements (quilombos, indigenous villages, caiçaras communities) where the crop production system focuses mainly on guaranteeing the subsistence of the local population; since producers use only the local varieties, existence of a wide genetic base is an intrinsic advantage in this system of crop production.

The basis for improvement of any crop is in the genetic variability available for selection. Efficient use of this variability depends, firstly, on a well-maintained and meaningful collection of the available intra-and interspecific variation; secondly, on a thorough evaluation of the characteristics of each accession; thirdly, on an advanced test program to evaluate the best materials under representative conditions, and, finally, on a hybridization program to combine the desirable characteristics of different genotypes (CARDOSO et al., 2005).

Under the hypothesis that there is ample genetic variability among the accessions of Ipomoea batatas maintained by farmers, this work aimed to rescue and evaluate the genetic divergence in accessions collected in traditional communities of Vale do Ribeira.

\section{MATERIAL AND METHODS}

Samples, either branches or roots were collected from sweet potato plants grown in traditional communities of Vale do Ribeira (South of the state of São Paulo): quilombos (Afro-Brazilian descendants of slaves who escaped from slave plantations that existed until abolition of slavery in 1888); indigenous villages, and caiçaras communities (traditional communities of the Atlantic Rainforest along Brazil's south and southeast coast). Accessions were also collected between February and November of 2013 in seven municipalities by small farmers as well as in the peri-urban gardens 
where they cultivate this vegetable for subsistence.

At each collection point, the municipality, location (community or neighborhood description), donor name and geographic coordinates were registered upon receiving an identification/code. The code elaborated was constructed taking into account the region, year, and collection number. The gathering of young branches of sweet potatoes was then carried out. In the absence of branches, roots were sampled; this material was then identified, stored in paper bags, and transported to the laboratories at Universidade Estadual Paulista,
Campus de Registro.

Ninety-five sweet potato accessions were collected in seven municipalities covering all i.e., high, medium, and low- regions of the Vale do Ribeira (Table 1), which represent $30 \%$ of the municipalities in the region.

Ninety-five sweet potato accessions were collected in seven municipalities covering all i.e., high, medium, and low- regions of the Vale do Ribeira (Tables 1 and 2), which represent $30 \%$ of the municipalities in the region.

Table 1. Code (1 to 34), city, place, height above mean sea level and coordinates of the points of collection of the accessions of sweet potatoes in the Vale do Ribeira.

\begin{tabular}{|c|c|c|c|c|c|}
\hline \multirow{2}{*}{ Code } & \multirow{2}{*}{ City } & \multirow{2}{*}{ Location } & \multirow{2}{*}{$\mathrm{ASL}^{*}(\mathrm{~m})$} & \multicolumn{2}{|c|}{ Coordinates } \\
\hline & & & & Latitude & Longitude \\
\hline VR13-01, 2 & Cananéia & Quilombo Mandira & 8 & $-24^{\circ} 59^{\prime} 46^{\prime \prime}$ & $-48^{\circ} 03^{\prime} 09^{\prime \prime}$ \\
\hline VR13-03 & Cananéia & Sítio Nova Esperança & 20 & $-24^{\circ} 57^{\prime} 27^{\prime \prime}$ & $-47^{\circ} 59^{\prime} 21^{\prime \prime}$ \\
\hline VR13-04, 5 & Cananéia & Quilombo Mandira & 11 & $-24^{\circ} 59^{\prime} 44^{\prime \prime}$ & $-48^{\circ} 01^{\prime} 59^{\prime \prime}$ \\
\hline VR13-06 & Cananéia & Quilombo Mandira & 11 & $-24^{\circ} 59^{\prime} 44^{\prime \prime}$ & $-48^{\circ} 01^{\prime} 59^{\prime \prime}$ \\
\hline VR13-07 & Cananéia & Quilombo Mandira & 20 & $-24^{\circ} 59^{\prime} 44^{\prime \prime}$ & $-48^{\circ} 02^{\prime} 07^{\prime \prime}$ \\
\hline VR13-08, 9 & Cananéia & Sítio Nova Esperança & 7 & $-24^{\circ} 57^{\prime} 27^{\prime \prime}$ & $-47^{\circ} 59^{\prime} 21^{\prime \prime}$ \\
\hline VR13-10 & Cananéia & Povoado Itapitangui & 14 & $-24^{\circ} 56^{\prime} 07^{\prime \prime}$ & $-47^{\circ} 57^{\prime} 25^{\prime \prime}$ \\
\hline VR13-11, 12 & Cananéia & Rio Branco & 37 & $-24^{\circ} 54^{\prime} 17^{\prime \prime}$ & $-48^{\circ} 00^{\prime} 25^{\prime \prime}$ \\
\hline VR13-13 & Cananéia & Rio Branco & 21 & $-24^{\circ} 54^{\prime} 17^{\prime \prime}$ & $-48^{\circ} 00^{\prime} 25^{\prime \prime}$ \\
\hline VR13-14, 15, 16 & Registro & Quilombo Peropava & 38 & $-24^{\circ} 26^{\prime} 42^{\prime \prime}$ & $-47^{\circ} 39^{\prime} 38^{\prime \prime}$ \\
\hline VR13-17, 18, 19 & Registro & Quilombo Peropava & 41 & $-24^{\circ} 26^{\prime} 45^{\prime \prime}$ & $-47^{\circ} 39^{\prime} 33^{\prime \prime}$ \\
\hline $\begin{array}{l}\text { VR13-20, 21, 22, 23, 24, } \\
25\end{array}$ & Registro & Quilombo Peropava & 33 & $-24^{\circ} 26^{\prime} 34^{\prime \prime}$ & $-47^{\circ} 39^{\prime} 36^{\prime \prime}$ \\
\hline VR13-26, 27, 28, 29, 30 & Registro & Quilombo Peropava & 67 & $-24^{\circ} 26^{\prime} 44^{\prime \prime}$ & $-47^{\circ} 39^{\prime} 39^{\prime \prime}$ \\
\hline VR13-31, 32, 33 & Registro & Quilombo Peropava & 19 & $-24^{\circ} 26^{\prime} 34^{\prime \prime}$ & $-47^{\circ} 39^{\prime} 29^{\prime \prime}$ \\
\hline VR13-34 & Eldorado & Quilombo Pedro Cubas & 27 & $-24^{\circ} 31^{\prime} 14^{\prime \prime}$ & $-48^{\circ} 17^{\prime} 27^{\prime \prime}$ \\
\hline
\end{tabular}

*Above sea level.

The evaluation of the germplasm collection was performed in the fields of the Experimental Farm of UNESP-Registro, $\left(24^{\circ} 32^{\prime} \mathrm{S}, 47^{\circ} 51^{\prime} \mathrm{W}\right.$, $25 \mathrm{~m}$ above sea level), between February and August 2014.

According to Köppen the climate is classified as Cfa (CEPAGRI, 2015), characterized by hot summers, trends of rainy concentrations in the summer months, yet with no definite dry season. Mean maximum and minimum temperatures during the study period were $29.5{ }^{\circ} \mathrm{C}$ and $19.3{ }^{\circ} \mathrm{C}$, respectively. Total precipitation was $532.3 \mathrm{~mm}$.

The experiment was laid in a randomized block design with 95 accessions collected in Vale do Ribeira, plus two commercial cultivars, 'Brazlândia Branca' and 'Brazlândia Roxa' (control treatments). Thus, the study comprised 97 treatments with three replicates. Each experimental plot consisted of 10 plants on one row with a useful area comprising the eight central plants on each row.

Cultivar 'Brazlândia Branca' is characterized by white skin and light creamed colored pulp. Roots are elongated and uniform in shape. Leaves are large, measuring 12 to $15 \mathrm{~cm}$ in length and 13 to $17 \mathrm{~cm}$ in width (EMBRAPA, 2015). As for cultivar 'Brazlândia Roxa,' it is characterized by a purple skin and a cream colored pulp. The shape of the roots is elongated and very uniform. The leaves, both the old and the new, are green in color, measuring 11 to $15 \mathrm{~cm}$ in length and 10 to $15 \mathrm{~cm}$ in width at the base (EMBRAPA, 2015).

The soil chemical properties at the plantation site were determined prior to establishing the study. Soil samples were collected from the 0-20 cm layer. These samples were sent to the Laboratory of Soil Fertility at the Unesp-Botucatu Campus.

Liming was carried out by manual application of $0.396 \mathrm{t} \mathrm{ha}^{-1}$ of dolomitic limestone to the soil in the study area two months before the transplant in order to raise the base saturation to $60 \%$ (MONTEIRO; PERESSIN, 1997). 
Table 2. Code (35 to 95), city, place, height above mean sea level and coordinates of the points of collection of the accessions of sweet potatoes in the Vale do Ribeira.

\begin{tabular}{|c|c|c|c|c|c|}
\hline \multirow{2}{*}{ Code } & \multirow{2}{*}{ City } & \multirow{2}{*}{ Location } & \multirow{2}{*}{$\mathrm{ASL}^{*}(\mathrm{~m})$} & \multicolumn{2}{|c|}{ Coordinates } \\
\hline & & & & Latitude & Longitude \\
\hline VR13-35, 36, 37, 38, 39 & Registro & Ribeirão Branco do Mota & 6 & $-24^{\circ} 22^{\prime} 36^{\prime \prime}$ & $-47^{\circ} 46^{\prime} 38^{\prime \prime}$ \\
\hline VR13-40 & Registro & Ribeirão Branco das Palmeiras & 6 & $-24^{\circ} 26^{\prime} 50^{\prime \prime}$ & $-47^{\circ} 45^{\prime} 56^{\prime \prime}$ \\
\hline VR13-41, 42 & Ilha Comprida & Pedrinhas & 4 & $-24^{\circ} 53^{\prime} 47^{\prime \prime}$ & $-47^{\circ} 47^{\prime} 56^{\prime \prime}$ \\
\hline VR13-43, 44 & Ilha Comprida & Pedrinhas & 5 & $-24^{\circ} 53^{\prime} 40^{\prime \prime}$ & $-47^{\circ} 47^{\prime} 41^{\prime \prime}$ \\
\hline VR13-45 & Ilha Comprida & Pedrinhas & 4 & $-24^{\circ} 50^{\prime} 37^{\prime \prime}$ & $-47^{\circ} 41^{\prime} 30^{\prime \prime}$ \\
\hline VR13-46 & Iguape & Carapara & 90 & $-24^{\circ} 41^{\prime} 08^{\prime \prime}$ & $-47^{\circ} 28^{\prime} 03^{\prime \prime}$ \\
\hline VR13-47 & Iguape & Fundão do Engenho & 146 & $-24^{\circ} 38^{\prime} 17^{\prime \prime}$ & $-47^{\circ} 29^{\prime} 42^{\prime \prime}$ \\
\hline VR13-48 & Iporanga & Quilombo São Pedro & 880 & $-24^{\circ} 31^{\prime} 24^{\prime \prime}$ & $-48^{\circ} 24^{\prime} 26^{\prime \prime}$ \\
\hline VR13-49 & Iporanga & Quilombo São Pedro & 59 & $-24^{\circ} 30^{\prime} 48^{\prime \prime}$ & $-48^{\circ} 23^{\prime} 24^{\prime \prime}$ \\
\hline VR13-50 & Iporanga & Quilombo São Pedro & 39 & $-24^{\circ} 22^{\prime} 08^{\prime \prime}$ & $-48^{\circ} 22^{\prime} 08^{\prime \prime}$ \\
\hline VR13-51 & Eldorado & Quilombo Ivaporunduva & 51 & $-24^{\circ} 33^{\prime} 52^{\prime \prime}$ & $-48^{\circ} 23^{\prime} 34^{\prime \prime}$ \\
\hline VR13-52 & Eldorado & Quilombo Ivaporunduva & 207 & $-24^{\circ} 33^{\prime} 00^{\prime \prime}$ & $-48^{\circ} 23^{\prime} 39^{\prime \prime}$ \\
\hline VR13-53, 54, 55, 56 & Iporanga & Quilombo Nhunguara & 24 & $-24^{\circ} 34^{\prime} 58^{\prime \prime}$ & $-48^{\circ} 24^{\prime} 37^{\prime \prime}$ \\
\hline VR13-57, 58, 59 & Eldorado & Quilombo Sapatu & 79 & $-24^{\circ} 31^{\prime} 54^{\prime \prime}$ & $-48^{\circ} 20^{\prime} 36^{\prime \prime}$ \\
\hline VR13-60 & Registro & Chacrinha & 87 & $-24^{\circ} 30^{\prime} 43^{\prime \prime}$ & $-47^{\circ} 51^{\prime} 16^{\prime \prime}$ \\
\hline VR13-61, 62 & Registro & Área urbana Registro & 188 & $-24^{\circ} 29^{\prime} 28^{\prime \prime}$ & $-47^{\circ} 53^{\prime} 22^{\prime \prime}$ \\
\hline VR13-63, 64 & Iporanga & Rodovia Benedito França & 48 & $-24^{\circ} 32^{\prime} 48^{\prime \prime}$ & $-48^{\circ} 29^{\prime} 59^{\prime \prime}$ \\
\hline VR13-65 & Iporanga & Rodovia Benedito França & 43 & $-24^{\circ} 32^{\prime} 48^{\prime \prime}$ & $-48^{\circ} 29^{\prime} 45^{\prime \prime}$ \\
\hline VR13-66 & Iporanga & Rodovia Benedito França & 26 & $-24^{\circ} 32^{\prime} 54^{\prime \prime}$ & $-48^{\circ} 28^{\prime} 10^{\prime \prime}$ \\
\hline VR13-70 & Iporanga & Rodovia Benedito França & 61 & $-24^{\circ} 32^{\prime} 54^{\prime \prime}$ & $-48^{\circ} 28^{\prime} 10^{\prime \prime}$ \\
\hline VR13-71, 72, 73, 74, 75 & Registrro & Agrocha & 44 & $-24^{\circ} 32^{\prime} 20^{\prime \prime}$ & $-47^{\circ} 53^{\prime} 21^{\prime \prime \prime}$ \\
\hline $\begin{array}{l}\text { VR13-76, 77, 78, 79, 80, } \\
81,82\end{array}$ & Sete Barras & Aldeia Peguao-Ty & 45 & $-24^{\circ} 13^{\prime} 42^{\prime \prime}$ & $-48^{\circ} 03^{\prime} 25^{\prime \prime}$ \\
\hline VR13-83, 84, 85 & Sete Barras & Sabadela/Sítio Freitas & 73 & $-24^{\circ} 15^{\prime} 55^{\prime \prime}$ & $-47^{\circ} 59^{\prime} 28^{\prime \prime}$ \\
\hline VR13-86 & Sete Barras & Área urbana Sete Barras & 73 & $-24^{\circ} 22^{\prime} 48^{\prime \prime}$ & $-47^{\circ} 55^{\prime} 46^{\prime \prime}$ \\
\hline VR13-87 & Sete Barras & Areado & 39 & $-24^{\circ} 21^{\prime} 05^{\prime \prime}$ & $-47^{\circ} 57^{\prime} 57^{\prime \prime}$ \\
\hline VR13-88, 89, 90 & Sete Barras & Areado & 8 & $-24^{\circ} 21^{\prime} 01^{\prime \prime}$ & $-47^{\circ} 58^{\prime} 05^{\prime \prime}$ \\
\hline VR13-91, 92 & Sete Barras & Areado & 20 & $-24^{\circ} 21^{\prime} 13^{\prime \prime}$ & $-47^{\circ} 57^{\prime} 02^{\prime \prime}$ \\
\hline VR13-93, 94, 95 & Sete Barras & Areado & 11 & $-24^{\circ} 21^{\prime} 28^{\prime \prime}$ & $-47^{\circ} 57^{\prime} 41^{\prime \prime}$ \\
\hline
\end{tabular}

*Above sea level.

On 1st February 2014, each accession was propagated from sweet potato mini-cuttings removed from the middle and upper thirds of selected branches, with two nodes each (RÓS; NARITA, 2011). Seedlings were watered twice daily, in the morning and then in the evening.

Grooves $40 \mathrm{~cm}$ high were raised one meter apart at the same time that manual planting fertilization was performed by mixing the soil with $500 \mathrm{~kg} \mathrm{ha}^{-1}$ of the formula $4: 14: 8,133 \mathrm{~kg} \mathrm{ha}^{-1}$ of potassium chloride and $166 \mathrm{~kg} \mathrm{ha}{ }^{-1}$ of simple superphosphate, for a final dosage of 20, 100 and $120 \mathrm{~kg} \mathrm{ha}^{-1}$ of nitrogen, phosphorus and potassium, respectively (MONTEIRO; PERESSIN, 1997).

Seedlings were transplanted to the permanent site on February 24, once they were completely developed. Row spacing of $1 \mathrm{~m}$ and a distance of $0.25 \mathrm{~m}$ between plants gave a final stand of 40 thousand plants $\mathrm{ha}^{-1}$. Topdressing with $66 \mathrm{~kg} \mathrm{ha}^{-1}$ urea in order to provide $30 \mathrm{~kg} \mathrm{ha}^{-1}$ nitrogen (MONTEIRO; PERESSIN, 1997) was done on March 14. There was no need for pest or disease control measures. Manual weed control was carried out 20 and 40 days after seedling transplant.

Evaluation of vegetative shoots started on May 17, when plants had undergone enough vegetative growth to appear well established in the field. Morphological characteristics of shoots and roots of each accession were evaluated. The characterization regarding the attributes of the shoots were obtained from the central part of the branches, using three leaves per plant and four plants per plot. For the characterization of the roots, two roots were selected representing the entire portion in relation to the size, shape, and mass.

Morphological characterization based on 23 descriptors of roots and shoots of sweet potato plants was carried out following the methodology described by Huamán (1992). Descriptors included: leaf size; general leaf profile; type of leaf lobe; number of leaf lobes; shape of the central lobe of the leaf; mature leaf color; immature leaf color; petiole pigmentation; petiole length; lower ribs pigmentation; predominant color of the branches; secondary color of the 
branches; pubescence of the apex of branches; stem length; root shape; defects on the surface of the root; cortical thickness; predominant color of the periderm; periderm color intensity; secondary color of the periderm; predominant color of the pulp; secondary color of the pulp; and distribution of the secondary color of the pulp. For each descriptor, there were different numbers of phonotype class, each phenotype class assigned a note. For example, phenotype classes for leaf size were preestablished as; small $(<8 \mathrm{~cm})$, medium $(8-15 \mathrm{~cm})$, large $(16-25 \mathrm{~cm})$ or very large $(>25 \mathrm{~cm})$, for which assigned notes were $3 ; 5 ; 7$ or 9 , respectively.

To study the genetic divergence among the accessions, multivariate analysis on the morphological data was performed, since morphological traits in germplasm description are less influenced by the environment (MENEZES et al., 2011; VIEIRA et al., 2008). Thus, the estimated genetic distance matrix was elaborated using the multi-category variables, the data being subsequently grouped by the modified method of Tocher, which is based on the formation of groups whose distances within groups are smaller than the distances between groups (FARIA et al., 2012). Analysis of the relative contribution of each characteristic to the genetic divergence was practiced according to the method proposed by Singh (1981) and phenotypic correlation between paired descriptors was estimated by Pearson correlation coefficients.

The magnitude of the correlation coefficients was classified according to the criteria proposed by
Carvalho, Lorencetti and Benin (2004): $0=$ nil; 0.1 to $0.30=$ weak; mean $=0.31$ to $0.60 ;$ strong $=0.61$ to 0.90 ; very strong $=0.91$ to 1 .

All analyzes were performed with the aid of Genes software (CRUZ, 2013).

\section{RESULTS AND DISCUSSION}

One hundred and seventy two morphological classes divided into 23 morphological traits of roots and shoots of sweet potatoes were evaluated. Results evidenced the expression of $70.35 \%$ of these classes. Nine descriptors, including shape of the central lobe of the leaf, immature leaf color, lower ribs pigmentation, predominant color of the branches, secondary color of the branches, stem length, root shape, pubescence of the apex of branches, and periderm color intensity, accounted for the expression of more than $85 \%$ of the possible classes within each descriptor (Figure 1).

Despite inescapable difficulties in classifying plant morphological characteristics due to subjectivity, this methodology for the study of germplasm diversity is often the method of choice (FONGOD; MIH; NKWATOH, 2012), given the easiness of application and its low cost (VIEIRA et al., 2008).

The descriptor's mature leaf color, secondary color of the periderm, and cortical thickness, showed lower level of expression in the different possible classifications (Figure 1).

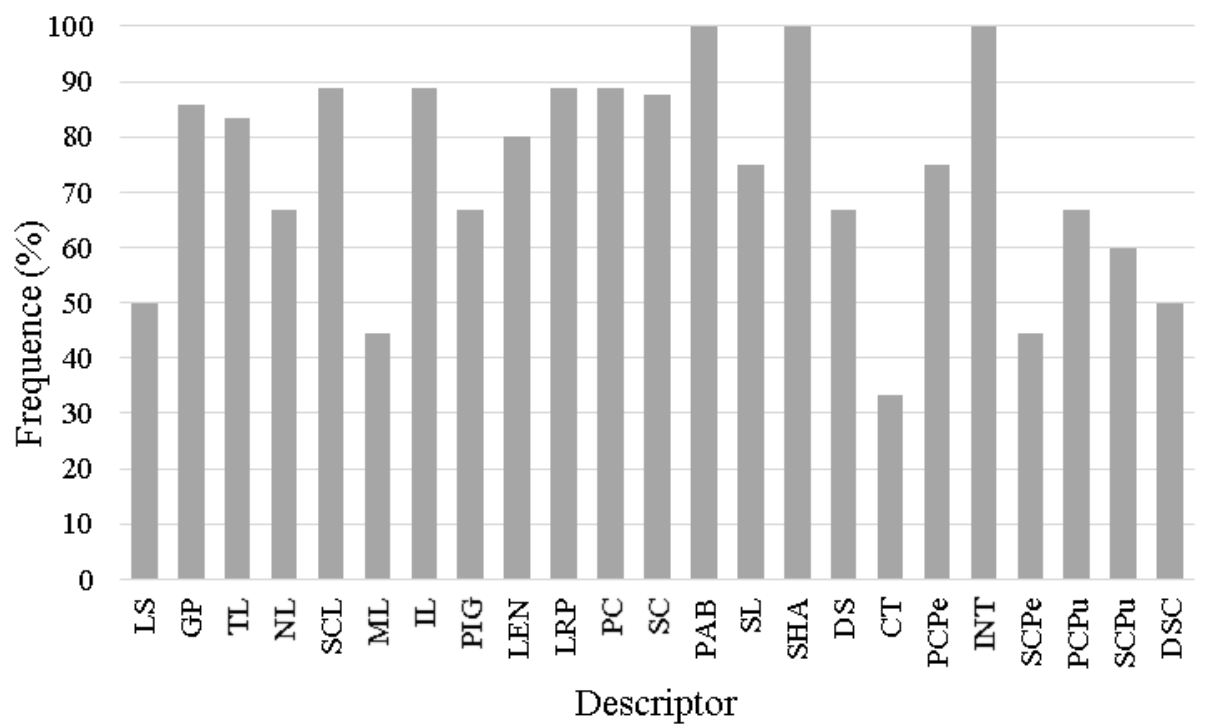

Figure 1. Percentage of expression of morphological classes in their descriptors: LS, leaf size; GP, general leaf profile; TL, type of leaf lobe; NL, number of leaf lobes; SCL, shape of the central lobe of the leaf; ML, mature leaf color; IL, immature leaf color; PIG, petiole pigmentation; LEN, petiole length; LRP, lower ribs pigmentation; PC, predominant color of the branches; SC, secondary color of the branches; PAB, pubescence of the apex of branches; SL, stem length; SHA, root shape; DS, defects on the surface of the root; CT, cortical thickness; PCPe, predominant color of the periderm; INT, periderm color intensity; SCPe, secondary color of the periderm; $\mathrm{PCPu}$, predominant color of the pulp; $\mathrm{SCPu}$, secondary color of the pulp; DSC, distribution of the secondary color of the pulp. 
Cluster analysis run on the basis of 23 morphological traits of sweet potato accessions collected and grouped by Tocher's method, enabled classification of the 95 accessions collected in Vale do Ribeira and two commercial cultivars, in 11 groups; This high number of groups confirmed the existence of a desirable large degree of genetic variability among the accessions studied (Table 3) since, based on the formation of these 11 groups, it is possible to select divergent genotypes for hybridization. As Casassola et al. (2013) have pointed, parental selection is an important first step in any breeding program and the genetic diversity found in this study guaranties ample opportunity for crossings between divergent genotypes to promote expression of large genetic variability in the segregating offspring, which in turn will surely allow selection of promising genotypes to be selected for agronomic superiority.

Our results showed the grouping of 70 accessions in group I, including the two commercial cultivars, Brazlândia Branca (VR13-96) and
Brazlândia Roxa (VR13-97). A previous study to determine the magnitude of genetic divergence among 135 accessions of sweet potatoes using morphological descriptors (FABRI, 2009) verified that accessions did not group together by color or geographic region, indeed, very distant accessions can be morphologically similar, even duplicates, a fact also verified in the present study, especially by the integration of group I.

Group II included six accessions, four of them collected in the quilombo Peropava (VR13-16; VR13-25; VR13-27; and VR13-33). We conclude that, although collections have occurred in subsistence gardens of different quilombos, either they are the same genotype or they are genetically close. A common practice among the residents of quilombos is the exchange of landraces. The other two accessions in this group were collected in the quilombo Nhunguara (VR13-53) and in the rural neighborhood of Sabadela, municipality of Sete Barras (VR13-83), respectively.

Table 3. Clusters determined by the Tocher method for 97 sweet potato genotypes evaluated on the basis of 23 morphological descriptors.

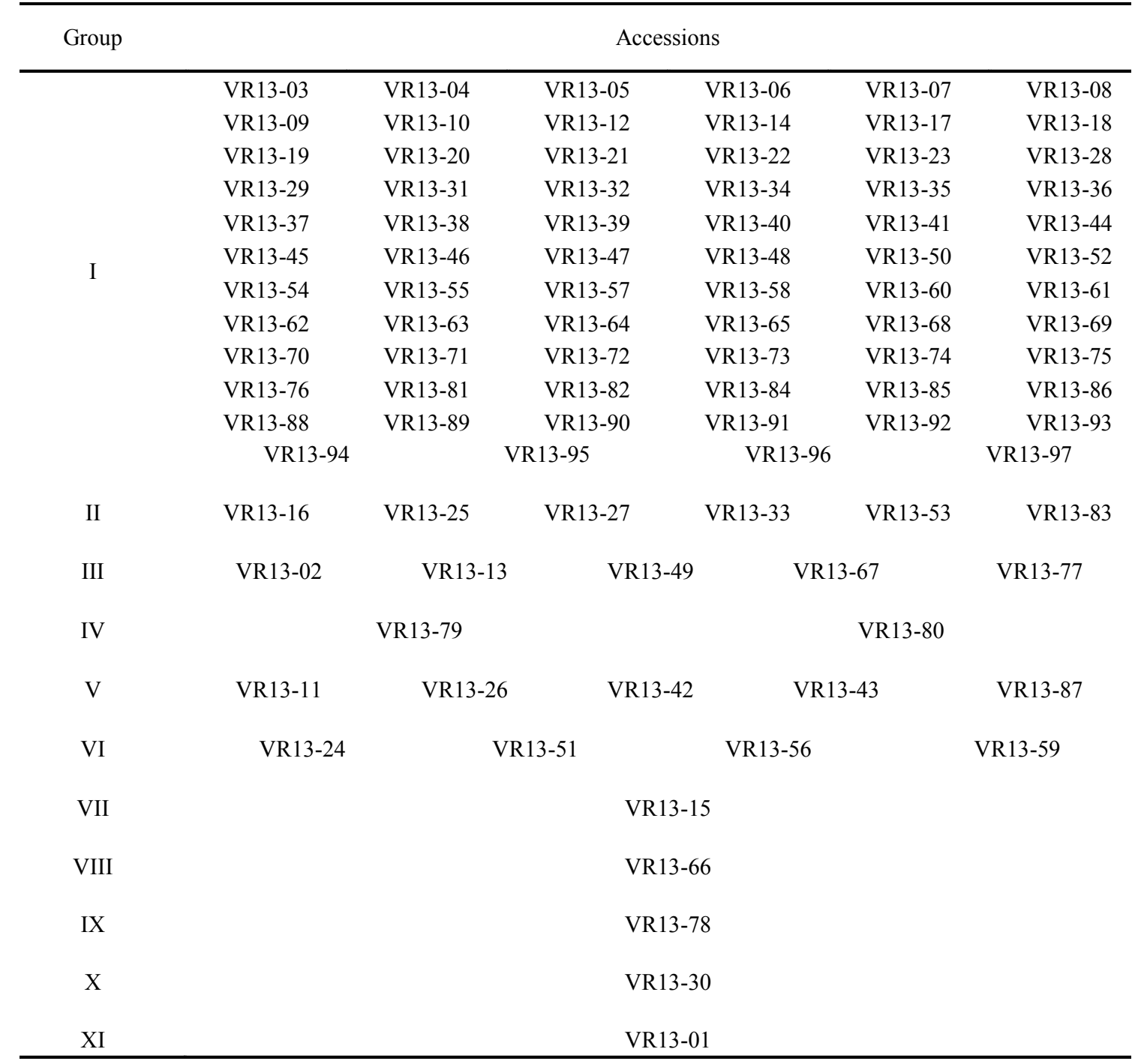


The third group contained five accessions collected in the quilombo Mandira (VR13-02), rural neighborhood of Rio Branco, municipality of Cananéia (VR13-13), quilombo São Pedro (VR13-49), rural neighborhood of Iporanga (VR13 -67) and Indian village Peguao-Ty (VR13-77).

Two accessions were grouped in group IV, collected in the Indian village Peguao-Ty (VR13-79 and VR13-80) which are therefore genetically close.

Group V included five accessions, two of them (VR13-42 and VR13-43) from the city of Ilha Comprida, in Pedrinhas. Although they were collected in different gardens (Table 3), quite likely they are duplicate accessions or, at least, genetically closely related. Using morphological descriptors and grouping by the agglomerative method UPGMA (unweighted pair group method with arithmetic mean) Veasey et al. (2007) also found two accessions genetically close which were collected at the same site. The rest of the accessions in this group were collected in the rural neighborhood of Rio Branco, municipality of Cananéia (VR13-11), quilombo Peropava (VR13-26) and rural neighborhood of Areado, of Sete Barras (VR13-87).

As shown in Table 3, the four members in group VI were all collected in quilombos: Peropava (VR13-24), Ivaporunduva (VR13-51), Nhunguara (VR13-56) and Sapatu (VR13-59).

Groups VII, VIII, IX, X and XI (Table 3) had only one accession each: VR13-15 (quilombo Peropava), VR13-66 (rural neighborhood of Iporanga), VR13-78 (village Paguao-Ty), VR13-30 (quilombo Peropava) and VR13-01 (quilombo Mandira)

The number of groups established by the Tocher grouping in this study was higher than that found by Oliveira et al. (2000) who, using 51 accessions from different regions of the country (MG, MS, TO, ES, SP and BA), observed the formation of seven groups using the same method. In contrast, studies by Maquia et al. (2013) based on morphological descriptors and grouping of 44 accessions from different countries (Mozambique, South Africa, Zimbabwe, Kenya, Uganda, United States, Nigeria and Peru), by UPGMA method, registered the formation of six groups of similarity.

The high number of groups formed from the germplasm collection under study here compares to the report by Beviláqua et al. (2014), in which the authors propose that the evolution of agriculture, especially in Brazil, has led to the emergence of several troubling issues for society, including genetic erosion.

Notwithstanding, the cultivation of staple foods for livelihood continues in traditional communities, unaltered by the evolutionary process undergone by commercial agriculture; alien to market principles and hunger for profit. In this respect, other attributes are equally or more important than productivity alone. Allied to this issue, the form of pollination in sweet potato, whose self-incompatibility guarantees cross-pollination, enhances genetic variability. Traditional selection, planting and maintenance practices carried out in these communities, all lead to the maintenance and expansion of genetic variability.

The relative contribution of each of the morphological characteristics to genetic divergence is shown in Table 4. Low amplitude was found between the feature that most contributed to the divergence (secondary color of the branches) and the one which least contributed to it (secondary color of the periderm).

The characteristics that most contributed to the genetic divergence among accessions were: secondary color of the branches $(8.44 \%)$, cortical thickness $(7.05 \%)$, periderm color intensity $(5.97 \%)$, stem length $(5.77 \%)$ and leaf size $(5.36 \%)$. As for the features that least contributed, these included: secondary color of the periderm $(1.46 \%)$, mature leaf color $(1.6 \%)$, secondary color of the pulp $(1.78 \%)$, petiole length $(2.27 \%)$ and defects on the surface of the root $(2.45 \%)$.

Unlike the findings reported here, based on the analysis of 25 features Oliveira et al. (2000) found characteristics which contributed as much as $35.79 \%$ (distribution of the secondary color of the pulp) to the genetic divergence in a collection comprising 51 accessions. In the present study, the top five characteristics together amounted to a relative contribution of $32.59 \%$ to the genetic diversity reported, yet in the aforementioned study the corresponding value was $79.53 \%$.

The knowledge of the degree of genetic closeness among objects in a large collection through correlation studies can identify traits that could be used as indirect selection criteria for yield or as secondary traits, thus improving the efficiency of the selection process (NEDER et al., 2013). A positive and strong correlation has been observed (CARVALHO; LORENCETTI; BENIN, 2004) between general leaf profile and type of leaf lobe $\left(0.763^{* *}\right)$, number of leaf lobes $\left(0.727^{* *}\right)$ and shape of the lobe $\left(0.725^{* *}\right)$; while a negative, mean correlation was registered between general leaf profile and immature leaf color $\left(-0.332^{* *}\right)$ and pubescence of the apex of branches $(-0.447 * *)$ (Table 4).

The type of leaf lobe showed positive and strong correlation with number of leaf lobes $\left(0.744^{* *}\right)$ and shape of the central lobe of the leaf $\left(0.773^{* *}\right)$; but negative, mean correlation with pubescence of the apex of the leaf. 
Table 4. Relative contribution of 23 morphological traits in sweet potato, to the genetic divergence estimated by the methodology proposed by Singh (1981).

\begin{tabular}{lc}
\hline Morphological Descriptor & Relative Contribution (\%) \\
\hline Leaf size & 5.36 \\
General leaf profile & 5.34 \\
Type of leaf lobe & 3.22 \\
Number of leaf lobes & 3.78 \\
Shape of the central lobe of the leaf & 3.78 \\
Mature leaf color & 1.60 \\
Immature leaf color & 5.10 \\
Petiole pigmentation & 5.31 \\
Petiole length & 2.27 \\
Lower ribs pigmentation & 5.13 \\
Predominant color of the branches & 5.08 \\
Secondary color of the branches & 8.44 \\
Pubescence of the apex of branches & 4.85 \\
Stem length & 5.77 \\
Root shape & 3.99 \\
Defects on the surface of the root & 2.45 \\
Cortical thickness & 7.05 \\
Predominant color of the periderm & 5.22 \\
Periderm color intensity & 5.97 \\
Secondary color of the periderm & 1.46 \\
Predominant color of the pulp & 4.25 \\
Secondary color of the pulp & 1.78 \\
Distribution of the secondary color of the pulp & 2.66 \\
\hline
\end{tabular}

As for the number of leaf lobes, this trait showed positive and strong correlation with shape of the central lobe of the leaf $\left(0.641^{* *}\right)$; and negative, mean correlation with pubescence of the apex of the leaf $\left(-0.321^{* *}\right)$. The shape of the central lobe of the leaf showed negative and strong correlation with pubescence of the apex of branches $\left(-0.513^{* *}\right)$.

Table 5. Phenotypic correlation matrix (LS to LEN) for morphological traits evaluated in 97 accessions of sweet potato using Pearson correlation coefficients.

\begin{tabular}{|c|c|c|c|c|c|c|c|c|}
\hline & GP & $\mathrm{TL}$ & $\mathrm{NL}$ & SCL & ML & IL & PIG & LEN \\
\hline $\mathrm{LS}$ & 0.075 & -0.102 & 0.003 & 0.056 & -0.149 & -0.108 & -0.145 & 0.188 \\
\hline GP & & $0.763 * *$ & $0.727 * *$ & $0.725 * *$ & $-0.226^{*}$ & $-0.332 * *$ & 0.059 & 0.106 \\
\hline $\mathrm{TL}$ & & & $0.744 * *$ & $0.773 * *$ & $-0.240^{*}$ & $-0.292 * *$ & 0.139 & 0.044 \\
\hline NL & & & & $0.641 * *$ & -0.185 & $-0.234^{*}$ & 0.157 & 0.122 \\
\hline SCL & & & & & -0.186 & $-0.227^{*}$ & 0.121 & -0.031 \\
\hline ML & & & & & & 0.176 & 0.018 & -0.036 \\
\hline IL & & & & & & & $0.269 * *$ & 0.036 \\
\hline PIG & & & & & & & & -0.144 \\
\hline
\end{tabular}

**, *Significantly different at $1 \%$ and $5 \%$ probability, respectively, according to a t test. LS, leaf size; GP, general leaf profile; TL, type of leaf lobe; NL, number of leaf lobes; SCL, shape of the central lobe of the leaf; ML, mature leaf color; IL, immature leaf color; PIG, petiole pigmentation; LEN, petiole length. 
Table 6. Phenotypic correlation matrix (LS to SHA) for morphological traits evaluated in 97 accessions of sweet potato using Pearson correlation coefficients.

\begin{tabular}{llllllll}
\hline & LRP & PC & SC & PAB & SL & SHA & DS \\
\hline LS & -0.167 & 0.030 & -0.123 & 0.120 & -0.026 & -0.031 & -0.014 \\
\hline GP & -0.128 & -0.013 & $-0.205^{*}$ & $-0.447^{* *}$ & $-0.250^{*}$ & -0.022 & 0.096 \\
\hline TL & -0.088 & 0.025 & -0.149 & $-0.395^{* *}$ & -0.197 & -0.028 & 0.005 \\
\hline NL & -0.054 & 0.025 & -0.032 & $-0.321^{* *}$ & $-0.257^{*}$ & -0.017 & 0.168 \\
\hline SCL & -0.072 & 0.081 & $-0.249^{*}$ & $-0.513^{* *}$ & $-0.289^{* *}$ & 0.097 & -0.016 \\
\hline ML & $0.376^{* *}$ & 0.015 & $0.278^{* *}$ & 0.188 & 0.051 & 0.022 & 0.044 \\
\hline IL & $0.286^{* *}$ & $0.350^{* *}$ & $0.278^{* *}$ & $0.290^{* *}$ & 0.075 & 0.017 & 0.061 \\
\hline PIG & $0.324^{* *}$ & $0.728^{* *}$ & -0.178 & -0.191 & -0.140 & 0.088 & -0.016 \\
\hline LEN & 0.010 & -0.083 & 0.071 & 0.111 & -0.085 & -0.013 & 0.115 \\
\hline LRP & & $0.215^{*}$ & $0.284^{* *}$ & 0.122 & 0.066 & 0.013 & $0.197^{*}$ \\
\hline PC & & -0.175 & -0.085 & -0.185 & 0.124 & 0.035 \\
\hline SC & & & $0.312^{* *}$ & 0.173 & 0.003 & 0.055 \\
\hline PAB & & & & 0.142 & -0.150 & 0.039 \\
\hline SL & & & & & 0.097 & 0.070 \\
\hline SHA & & & & & & $0.219^{*}$ \\
\hline
\end{tabular}

**, *Significantly different at $1 \%$ and $5 \%$ probability, respectively, according to a t test. LS, leaf size; GP, general leaf profile; TL, type of leaf lobe; NL, number of leaf lobes; SCL, shape of the central lobe of the leaf; ML, mature leaf color; IL, immature leaf color; PIG, petiole pigmentation; LEN, petiole length; LRP, lower ribs pigmentation; PC, predominant color of the branches; SC, secondary color of the branches; PAB, pubescence of the apex of branches; SL, stem length; SHA, root shape; DS, defects on the surface of the root.

Considering all the correlations presented above between the paired traits under study and the relative contribution by each of them to the diversity among the accessions, only general leaf profile should be gauged, since it contributed most significantly to the genetic divergence among the accessions (5.34\%). This correlation, indirectly, represents the type characteristics of leaf lobe, number of leaf lobes, lobe shape, immature leaf color and pubescence of leaf apex. Besides saving time, money and hand labor, this indirect selection made through correlated characteristics, allows to characterize more complex or difficult traits under indirect selection through selection of the correlated character (GONÇALVES NETO et al., 2012). The following paired traits were strongly correlated: petiole pigmentation and predominant color of the branches $\left(0.728^{* *}\right)$; secondary color of the periderm and predominant color of the pulp $\left(0.532^{* *}\right)$; predominant color of the pulp and distribution of the secondary color of the pulp $\left(0.742^{* *}\right)$ and, secondary color of the pulp and distribution of the secondary color $\left(0.717^{* *}\right)$.

There was also a mean correlation between mature leaf and lower ribs pigmentation $\left(0.376^{* *}\right)$; immature leaf and petiole lengths $\left(0.350^{* *}\right)$; petiole pigmentation and lower ribs pigmentation $\left(0.324^{* *}\right)$ (Table 6); predominant color of the branches and predominant color of the periderm $\left(-0.343^{* *}\right)$, periderm color intensity $\left(-0.305^{* *}\right)$ and predominant color of the pulp $\left(0.323^{* *}\right)$; secondary color of the branches and pubescence of the apex of branches $\left(0.312^{* *}\right)$; secondary color of the periderm and secondary color of the pulp $\left(0.353^{* *}\right)$ and distribution of the secondary color $\left(0.431^{* *}\right)$ (Table 7$)$.

There were other significant correlations by t-test; however, due to the low correlation coefficient ( 0.1 to 0.30$)$, these values should be taken with caution (Tables 5, 6 and 7). 
P. F. VARGAS et al.

Table 7. Phenotypic correlation matrix (LS to SCPu) for morphological traits evaluated in 97 accessions of sweet potato using Pearson correlation coefficients.

\begin{tabular}{lllllllll}
\hline & DS & CT & PCPe & INT & SCPe & PCPu & SCPu & DSC \\
\hline LS & -0.014 & -0.029 & -0.173 & -0.177 & -0.070 & -0.150 & -0.062 & -0.053 \\
\hline GP & 0.096 & $-0.200^{*}$ & 0.022 & $0.237^{*}$ & -0.037 & 0.119 & -0.059 & 0.121 \\
\hline TL & 0.005 & -0.166 & -0.043 & 0.130 & -0.138 & 0.168 & -0.051 & 0.143 \\
\hline NL & 0.168 & $-0.198^{*}$ & -0.072 & 0.186 & -0.099 & 0.143 & -0.078 & 0.116 \\
\hline SCL & -0.016 & -0.120 & -0.085 & 0.107 & -0.141 & $0.219^{*}$ & -0.057 & 0.163 \\
\hline ML & 0.044 & -0.053 & 0.008 & -0.036 & 0.112 & -0.030 & -0.047 & -0.034 \\
\hline IL & 0.061 & 0.174 & -0.152 & -0.154 & $-0.098^{*}$ & 0.058 & 0.213 & 0.194 \\
\hline PIG & -0.016 & 0.156 & $-0.206^{* *}$ & -0.035 & -0.110 & $0.299^{* *}$ & 0.122 & $0.279^{* *}$ \\
\hline LEN & 0.115 & 0.082 & -0.090 & -0.170 & -0.083 & $-0.236^{*}$ & -0.135 & $-0.225^{*}$ \\
\hline LRP & $0.197^{*}$ & 0.114 & -0.141 & 0.012 & 0.154 & 0.076 & -0.017 & 0.018 \\
\hline PC & 0.035 & $0.217^{*}$ & $-0.343^{* *}$ & $-0.305^{* *}$ & -0.130 & $0.323^{* *}$ & -0.018 & $0.229^{*}$ \\
\hline SC & 0.055 & -0.080 & -0.037 & 0.056 & 0.067 & -0.119 & 0.109 & 0.068 \\
\hline PAB & 0.039 & 0.025 & -0.145 & -0.160 & 0.109 & -0.180 & 0.045 & -0.091 \\
\hline SL & 0.070 & 0.026 & 0.142 & 0.140 & -0.057 & -0.192 & -0.017 & -0.116 \\
\hline SHA & $0.219^{*}$ & 0.009 & -0.130 & -0.105 & -0.229 & -0.061 & $-0.198^{*}$ & -0.159 \\
\hline DS & & -0.006 & -0.073 & 0.036 & $0.270^{* *}$ & 0.147 & -0.130 & 0.033 \\
\hline CT & & & $-0.210^{*}$ & -0.041 & -0.018 & 0.033 & 0.130 & -0.001 \\
\hline PCPe & & & $0.274^{* *}$ & $0.213^{*}$ & 0.058 & 0.172 & 0.040 \\
\hline INT & & & & & -0.032 & -0.112 & $0.217^{*}$ & 0.013 \\
\hline SCPe & & & & & & $0.532^{* *}$ & $0.353^{* *}$ & $0.431^{* *}$ \\
\hline PCPu & & & & & & $0.281^{* *}$ & $0.742^{* *}$ \\
\hline SCPu & & & & & & $0.717^{* *}$ \\
\hline
\end{tabular}

$* *$, Significantly different at $1 \%$ and $5 \%$ probability, respectively, according to a t test. LS, leaf size; GP, general leaf profile; TL, type of leaf lobe; NL, number of leaf lobes; SCL, shape of the central lobe of the leaf; ML, mature leaf color; IL, immature leaf color; PIG, petiole pigmentation; LEN, petiole length; LRP, lower ribs pigmentation; PC, predominant color of the branches; SC, secondary color of the branches; PAB, pubescence of the apex of branches; SL, stem length; SHA, root shape; DS, defects on the surface of the root; CT, cortical thickness; PCPe, predominant color of the periderm; INT, periderm color intensity; SCPe, secondary color of the periderm; $\mathrm{PCPu}$, predominant color of the pulp; $\mathrm{SCPu}$, secondary color of the pulp; DSC, distribution of the secondary color of the pulp.

\section{CONCLUSIONS}

According to the results, it can be concluded that there is wide genetic diversity among the sweet potato accessions collected in Vale do Ribeira; accessions did not group according to the collection point, and significant correlations between morphological descriptors were observed in $22.26 \%$ of the paired traits.

\section{ACKNOWLEDGEMENTS}

The authors thankfully acknowledge the Foundation for Research Support of the State of São Paulo - FAPESP - for the financial support to conduct the study (Proc. 2012/08763-0), and the Scientific Research Scholarship granted to the second author (Proc. 2013/15239-9).

\section{REFERENCES}

BEVILÁQUA, G. A. P. et al. Agricultores guardiões de sementes e ampliação da agrobiodiversidade. Cadernos de Ciência \& Tecnologia, Brasília, v. 31, n. 1, p. 99-118. 2014.

CARDOSO, A. D. et al. Avaliação de clones de batata-doce em Vitória da Conquista. Horticultura Brasileira, Brasília, v. 23, n. 4, p. 911-914. 2005.

CARVALHO, F. I. F.; LORENCETTI, C.; BENIN, G. Estimativas e implicações da correlação no melhoramento vegetal. Pelotas, RS: UFPel, 2004. $142 \mathrm{p}$.

CASASSOLA, A. B. et al. Parental selection of wheat lines based on phenotypic characterization and genetic diversity. Crop Breeding and Applied Biotechnology, Viçosa, v. 13, n. 1, p. 49-58. 2013. 
CENTRO DE PESQUISAS METEOROLÓGICAS E CLIMÁTICAS APLICADAS À AGRICULTURA - CEPAGRI. A classificação climática de Koeppen para o estado de São Paulo. Disponível em: $<$ http:/www.cpa.unicamp.br/outras-informacoes/ clima-dos-municipios-paulistas.html $>$. Acesso em: 12 fev. 2015.

CRUZ, C. D. GENES: a software package for analysis in experimental statistics and quantitative genetics. Acta Scientiarum. Agronomy, Maringá, v. 35, n. 3, p. 271-276, 2013.

EMPRESA BRASILEIRA DE PESQUISA AGROPECUÁRIA - EMBRAPA. Batata-Doce: 'Brazlândia Branca'; 'Brazlândia Roxa'; 'Brazlândia Rosada' e 'Coquinho'. Disponível em: $<$ http://www.cnph.embrapa.br/paginas/produtos/ cultivares/batata_doce_varias.htm $>$. Acesso em: 25 fev. 2015 .

FABRI, E. G. Diversidade genética entre acessos de bata-doce (Ipomoea batatas L. Lam.) avaliada através de marcadores microssatélites e descritores morfoagronômicos. 2009. 175 f. Tese (Doutorado em Fitotecnia) - Universidade de São Paulo, Piracicaba, 2009.

FARIA, P. N. et al. Métodos de agrupamento em estudo de divergência genética de pimentas. Horticultura Brasileira, Vitória da Conquista, v. 30, n. 3, p. 428-432. 2012.

FONGOD, A. G. N.; MIH, A. M.; NKWATOH, T. $\mathrm{N}$. Morphological and agronomical characterization of different accessions of sweet potato (Ipomoea batatas) in Cameroon. International Research Journal of Agricultural Science and Soil Science, New Jersey, v. 2, v. 6, p. 234-245, 2012.

FOOD AND AGRICULTURE ORGANIZATION OF THE UNITED NATIONS - FAO. Fao stat database gateway. Disponível em: <http:// faostat3.fao.org/home/E>. Acesso em: 5 mar. 2015.

GONÇALVES NETO, A. C. et al. Correlação entre caracteres e estimação de parâmetros populacionais para batata-doce. Horticultura Brasileira, Brasília, v. 30, n. 4, p. 713-719. 2012.

HUAMÁN, Z. Morphologic identification of duplicates in collections of Ipomoea batatas. Lima: International Potato Center. 1992. 28 p.

INSTITUTO BRASILEIRO DE GEOGRÁFIA E ESTATÍSTICA - IBGE. Estados. Disponível em: $<$ http://www.ibge.gov.br/estadosat/index.php>.

Acesso em: 20 ago. 2015.

MACIEL, G. M. et al. Genetic dissimilarity among the physiochemical characteristics of fruit from pepper accessions. Bioscience Journal, Uberlândia, v. 32 , n. 4 , p. $978-985.2016$

MAQUIA, I. et al. Molecular; morphological and agronomic characterization of the sweet potato (Ipomoea batatas L.) germplasm collection from Mozambique: Genotype selection for drought prone regions. South African Journal of Botany, Amsterdam, v. 88, n. 1, p. 142-151. 2013.

MENEZES, B. R. S. et al. Caracterização morfoagronômica em arroz vermelho e arroz de sequeiro. Pesquisa Agropecuária Tropical, Goiânia, v. 41, n. 4, p. 490-499. 2011.

MONTEIRO, D. A.; PERESSIN, V. A. Batata doce e cará. In: RAIJ, B. van et al. (Eds.). Recomendações de adubação e calagem para o Estado de São Paulo. Campinas: Instituto Agronômico \& Fundação IAC, 1997. v. 2, cap. 21, p. 226.

MUKHOPADHYAY, S. K. et al. Crops that feed the world 5. Sweetpotato. Sweet potatoes for income and food security. Food Security, Cham, v. 3, n. 3, p. 283-305. 2011.

NEDER, D. G. et al. Correlations and path analysis of morphological and yield traits of cactus pear accessions. Crop Breeding and Applied Biotechnology, Viçosa, v. 13, n. 3, p. 203-207. 2013

NSA, S. O.; OKON, D. P.; ROBERT, S. P. Comparative effects of chicken manure and NPK on the yield of Ipomoea batatas. Journal of Agricultural and Crop Research, Burntwood, v. 1, n. 6 , p. $90-93.2013$.

OLIVEIRA, A. C. B. et al. Avaliação da divergência genética em batata-doce por procedimentos multivariados. Acta Scientiarum. Agronomy, Maringá, v. 22, n. 4, p. 895-900. 2000.

OLIVEIRA, A. P. et al. Rendimento e qualidade de raízes de batata-doce adubada com níveis de uréia. Horticultura Brasileira, Brasília, v. 23, n. 4, p. $25-$ 928. 2005.

PARK, S. C. et al. Enhanced accumulation of carotenoids in sweetpotato plants overexpressing Ib Or-Ins gene in purple-fleshed sweetpotato cultivar. Plant Physiology and Biochemistry, Amsterdam, v. 86 , n. 1, p. 82-90, 2014

RITSCHEL, P. S.; HUAMÁN, Z. Variabilidade morfológica da coleção de germoplasma de batatadoce da Embrapa - Centro Nacional de Pesquisa de Hortaliças. Pesquisa Agropecuária Brasileira, 
Brasília, v. 37, n. 4, p. 485-492, 2002.

RÓS, A. B.; NARITA, N. Produção de mudas de batata-doce a partir de poucas plantas matrizes. Revista Brasileira de Ciências Agrárias, Recife, v. 6, n. 1, p. 85-89. 2011.

SILVA, A. V. C. et al. Genetic diversity of sweet potatoes collection from Northeastern Brazil. African Journal of Biotechnology, Nairobi, v. 13, n. 10, p. 1109-1116, 2014

SINGH, D. The relative importance of characters affecting genetic divergence. The Indian Journal of Genetics and Plant Breeding, New Delhi, v. 41, n. 2, p. 237-245. 1981.

THUMÉ, M. A. et al. Níveis críticos foliares de nutrientes de três cultivares de batata-doce, selecionados para a produção de etanol. Revista Ceres, Viçosa, v. 60, n. 6, p. 863-875. 2013.

VEASEY, A. E. et al. Phenology and morphological diversity of sweet potato (Ipomoea batatas) landraces of the Vale do Ribeira. Scientia Agricola, Piracicaba, v. 64, n. 4, p. 416-427. 2007.

VIEIRA, E. A. et al. Variabilidade genética do banco de germoplasma de mandioca da Embrapa Cerrados acessada por meio de descritores morfológicos. Científica, Jaboticabal, v. 36, n. 1, p. 56-67. 2008. 